\title{
Gazelles, industry growth and structural change
}

Citation for published version (APA):

Bos, J. W. B., \& Stam, E. (2011). Gazelles, industry growth and structural change. METEOR, Maastricht University School of Business and Economics. METEOR Research Memorandum No. 018 https://doi.org/10.26481/umamet.2011018

Document status and date:

Published: 01/01/2011

DOI:

10.26481/umamet.2011018

Document Version:

Publisher's PDF, also known as Version of record

\section{Please check the document version of this publication:}

- A submitted manuscript is the version of the article upon submission and before peer-review. There can be important differences between the submitted version and the official published version of record.

People interested in the research are advised to contact the author for the final version of the publication, or visit the DOI to the publisher's website.

- The final author version and the galley proof are versions of the publication after peer review.

- The final published version features the final layout of the paper including the volume, issue and page numbers.

Link to publication

\footnotetext{
General rights rights.

- You may freely distribute the URL identifying the publication in the public portal. please follow below link for the End User Agreement:

www.umlib.nl/taverne-license

Take down policy

If you believe that this document breaches copyright please contact us at:

repository@maastrichtuniversity.nl

providing details and we will investigate your claim.
}

Copyright and moral rights for the publications made accessible in the public portal are retained by the authors and/or other copyright owners and it is a condition of accessing publications that users recognise and abide by the legal requirements associated with these

- Users may download and print one copy of any publication from the public portal for the purpose of private study or research.

- You may not further distribute the material or use it for any profit-making activity or commercial gain

If the publication is distributed under the terms of Article $25 \mathrm{fa}$ of the Dutch Copyright Act, indicated by the "Taverne" license above, 


\section{Maastricht University}

Jaap W.B. Bos, Erik Stam

Gazelles, I ndustry Growth and Structural Change

$\mathrm{RM} / 11 / 018$

\section{METEOR}

Maastricht University School of Business and Economics

Maastricht Research School of Economics

of Technology and Organization

P.O. Box 616

NL - 6200 MD Maastricht

The Netherlands 


\title{
Gazelles, Industry Growth and Structural Change
}

\author{
Jaap W.B. Bos ${ }^{\mathrm{a}}$, Erik Stam ${ }^{\mathrm{b}, \mathrm{c}, \mathrm{d}, *}$ \\ ${ }^{a}$ School of Business and Economics, Maastricht University, 6200 MD Maastricht, The Netherlands \\ ${ }^{b}$ Utrecht University School of Economics, Utrecht University, Janskerkhof 12, 3512 BL, Utrecht, the Netherlands \\ ${ }^{c}$ Scientific Council for Government Policy, the Hague, The Netherlands \\ 'University of Cambridge, Cambridge, United Kingdom;
}

\begin{abstract}
This paper examines to what extent gazelles are the drivers of the growth of industries and structural change. To this purpose we analyze gazelles over a 12 year period (annually from 1997 until 2008) in the Netherlands, and relate them to the dynamics in employment per industry. We use a panel vector autoregressive (PVAR) model to explore the relations between the presence of gazelles and industry (employment) growth (with 43 two digit industries). An increase in the presence of gazelles in an industry appears to have a positive effect on the subsequent growth of the industry. We do not find evidence for an inverse causal relation: there are no long run positive effects of increases in industry growth on the presence of gazelles. There is also no relation between the overrepresentation of gazelles and subsequent industry growth.
\end{abstract}

Keywords: entrepreneurship, gazelles, industry growth, structural economic change

JEL: L16, L25, L26, M13

\section{Introduction}

The academic debate on entrepreneurship and economic growth has made substantial progress since the landmark article by Wennekers and Thurik (1999). Different types of entrepreneurship and their effect on regional and national economic growth in diverse contexts have been analysed in multiple studies (see for example Audretsch et al., 2006; Carree et al., 2007; Fritsch, 2008; Bosma, 2009; Stam et al., 2009, 2011). Despite this multitude of empirical studies, there is still no fully shared insight into what types of entrepreneurship matter for economic growth. This problem can be solved in a rhetorical way by focussing on high-quality entrepreneurs (Hvide, 2009), high-quality start-ups (Fritsch and Schroeter, 2009), or highpotential entrepreneurship (Lerner, 2010b). This however still leaves us with the empirical question of what exactly these propagated types of entrepreneurship are in reality, and how they affect economic growth. One of the candidates here is a group that has been labelled as gazelles: young, high growth firms. Even though there is no shared definition of gazelles, there seems to be a shared opinion that these firms are important for structural change in the economy (Acs, 2008; Acs and Mueller, 2008; Henrekson and Johansson, 2009), going back to the creative destruction theory by Schumpeter $(1934 ; 1942)$. This seems to be confirmed by evidence on gazelles in the emergence of new industries in regions like Silicon Valley (Saxenian, 1994) and Cambridgeshire (Stam and Martin, 2011).

\footnotetext{
चThe authors would like to thank Oliver Falck, Atsushi Ohyama, Karl Wennberg and seminar participants at the Max Planck Institute of Economics (Jena), the University of Cambridge - Institute for Manufacutring, Jönköping International Business School, Utrecht University School of Economics, Maastricht School of Management, and the Osaka Workshop on Entrepreneurship and Innovation for comments on prior versions of this paper. The usual disclaimer applies.

${ }^{*}$ Corresponding author.

Email addresses: j . bos@maastrichtuniversity.nl (Jaap W.B. Bos), e.stam@uu.nl (Erik Stam)
} 
In a broader policy context, these gazelles are seen as the seeds of industrial leadership, i.e. a regional or national set of firms that are ahead of their worldwide competitors in a specific product-market (cf. Mowery and Nelson, 1999). Key examples here are gazelles like Intel and Microsoft that have been instrumental in American leadership in the semiconductor and computer software industries. Gazelles are said to be overrepresented in young and growing industries (Davidsson and Delmar, 2006; Acs et al., 2008), and in innovative industries (Eckhardt and Shane, 2011). These gazelles are then the drivers of structural economic change, especially when incumbents have too much to loose by giving up there vested interests in long established markets (Arrow, 1962; Christensen, 1997). The study of the relation between gazelles and industry growth provides insights for industrial policy. Industrial policy has come back in demand again in many capitalist economies (The Economist, 2010). Industrial policy can have many appearances ranging from vertical (targeted) industrial policies in which governments pick winners or losers in the economy in order to stimulate the competitiveness of the economy or safeguarding jobs in industries that cannot stand international competition (target industries for protection or promotion), to horizontal industrial policies that reinforce competition and the overall development of markets. The traditional complaint against targeted industrial policies to pick winners is that governments cannot outguess markets in the allocation of capital, and that neither academics nor policy makers know how to identify 'strategic sectors' with any confidence (Krugman, 1986). More specifically, it is claimed that governments cannot predict an industry's future and that their policy making is liable to powerful vested interests that try to influence the choice of which industry to support (Krugman, 1993). Industrial policy is then likely to benefit mostly the owners of a few incumbent firms and hurt the overall economy. ${ }^{1}$

Governments have a bad track record in designing and implementing targeted industrial policies in a welfare enhancing way (Lerner, 2010a). If governments could find ways to improve their capacity to predict an industry's future, they would also become less susceptible to vested interests of established industries. There is no crystal ball which could be used to predict a capitalist economy's future industrial structure. A key element of capitalism is its restless character (Metcalfe et al., 2006) which makes the nature of its future industrial structure unpredictable by necessity. However, it could be that governments could analyze new market developments as signposts for probable future changes in the industrial structure of an economy. The roots of this approach can be found in Schumpeter's work on creative destruction and structural economic change, in which entrepreneurs create economic activities that form the basis of new industries that displace established industries (Schumpeter, 1934, 1942). The hypothesis would be that industries in which there is a relatively large presence of young substantial firms (i.e. Schumpeterian entrepreneurs) will be the industries that are likely to expand in the near future. In this way the initial uncertainty about the future development of an industry is taken away by the experiments of entrepreneurs that tried and succeeded to find opportunities in emerging industries.

The objective of this paper is to examine to what extent gazelles are the drivers of the growth of industries and structural change. For this we analyze gazelles over a 12 year period (annually from 1997 until 2008) in the Netherlands, and relate them to the dynamics in employment per industry. We use a panel vector autoregressive (VAR) model to explore the relations between the presence of gazelles and industry (employment) growth (with 43 two digit industries). An increase in the presence of gazelles in an industry seems to have a positive effect on the subsequent growth of the industry. We do not find evidence for an inverse causal relation: there are no long run positive effects of increases in industry growth on the presence of gazelles. There is also no relation between the overrepresentation of gazelles and subsequent industry growth.

\footnotetext{
${ }^{1}$ According to Witt (2003), the typical market situation in which interest groups pressure for subsidies and policy makers are inclined to grant them is one in which there is a tendency for politically significant producers to be driven out of the market. The causes usually are inflexible cost structures and/or competitive pressure on the prices. A situation like that regularly occurs at a stage of an industry's life cycle when an industry's overall market volume stagnates or shrinks (Klepper, 1996).
} 


\section{Gazelles and industry growth: causal mechanisms}

\subsection{Schumpeterian creative destruction}

According to Schumpeter (1942), economic change is driven by newcomers' innovations. These newcomers set in motion a process of industrial mutation "that incessantly revolutionizes the economic structure from within, incessantly destroying the old one, incessantly creating a new one": a process of creative destruction (Schumpeter, 1942, p. 83). This means that newcomers that successfully develop innovations (i.e. gazelles) are likely to create new industries. They accelerate the process of structural change. Gazelles are that part of the population of innovative newcomers that have successfully created a new market. They are the new industrial leaders that are 'drawn' from a pool of new economic experiments (Eliasson, 1991; Rosenberg, 1992). This would mean that both a concentration of gazelles and a growth in the number of gazelles in an industry would drive industry growth, created by these gazelles.

\subsection{Spin-offs and capabilities}

Recent findings on the evolution of industries show that de novo entrants founded by individuals that worked for the early industry leaders outperformed all firms and dominated the industry after the emergence phase (Klepper, 2002). This is attributed to the novel organizational challenges faced by firms during the early evolution of an industry, which made the leading firms ideal training grounds for new entrants. These spin-offs would have improved capabilities that enable them to outcompete other firms in the industry.

This would mean that an initial concentration of gazelles would indirectly (via the spin-offs of early industry leaders) lead to industry growth, and that a growth in the number of gazelles (i.e. the wave of successful spin-offs) would directly lead to industry growth.

\subsection{Alertness to environmental change}

The Austrian school of economics emphasizes the dynamic competitive process of entrepreneurial discovery (Kirzner, 1997). Entrepreneurial discovery is seen as gradually but systematically pushing back the boundaries of sheer ignorance, in this way increasing mutual awareness among market participants and thus, in turn, driving prices, output and input quantities and qualities, toward the values consistent with equilibrium (seen as the complete absence of sheer ignorance). Entrepreneurs that are relatively more alert for opportunities than managers of incumbent firms set up new firms to pursue these opportunities. In this way they act as signposts for more employment growth to come in their industry. The growth in employment could be due to the competitive effect of these gazelles on other suppliers, making the overall industry more competitive on the medium term (cf. Baumol et al., 1988; Fritsch, 2008), but the employment growth could also be realized by other firms that learn about this latent consumer demand from the alert entrepreneurs with their successful new firms. These alert entrepreneurs that pursue substantial new opportunities might be found in new as well as in more mature industries that somehow face structural changes in their environment. This would mean that we especially expect that a sudden increase in the number of gazelles is a signpost of subsequent industry growth, irrespective of the initial level of gazelles.

\section{Data}

In order to carry out our analysis, we need to define and measure what constitutes a gazelle, industry growth, and the growth of the presence of gazelles in an industry. We define a gazelle as a firm that is between 5 and 10 years old with at least 20 employees (see Stam, 2005, 2007). This means that although a firm could not yet be considered fully mature, it has at least survived the first 4 years of existence - which are generally characterized by the highest failure rates. Other studies have found that new firms that survive over the longer term (i.e. more than five years) contribute significantly and in a positive way to industry GDP, in contrast to new firms that only survive for one or a few years, which even contribute negatively to industry GDP (Falck, 2007). These firms have passed the most severe market test, by surviving the first 
years after start-up. To be a gazelle, firms also had to have generated at least 20 jobs (including the ownermanagers), which is a rough indicator of successful exploitation of entrepreneurial opportunities. Prior studies have shown that new firms that reach such a substantial size are much more important for employment growth in regions (Acs and Mueller, 2008) and countries (Stam et al., 2009; Stam and Nooteboom, 2011) than new firms that remain small.

Industry growth is measured as the percentage growth in industry employment, with time lags (to the point of measurement of gazelles) of 1 to 6 years, in order not to measure the direct (simultaneous) industry employment effect of gazelles (leading to a potentially tautological outcome).

Figure 1: Development of gazelles and sectoral employment

(a) Evolution of sectoral employment, 1997-2008

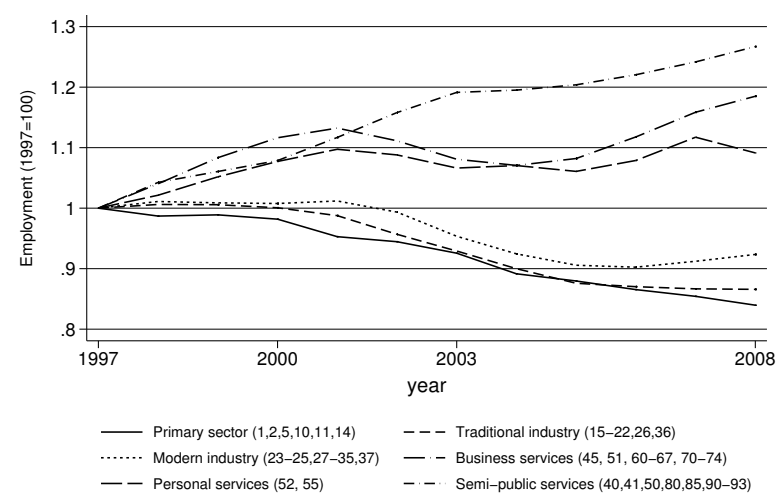

(b) Evolution of number of gazelles per industry, 1997-2008

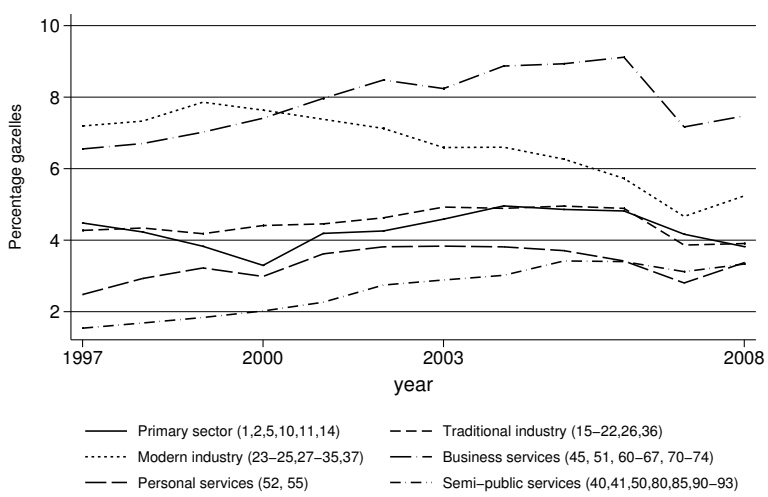

(c) Gazelles index, 1997

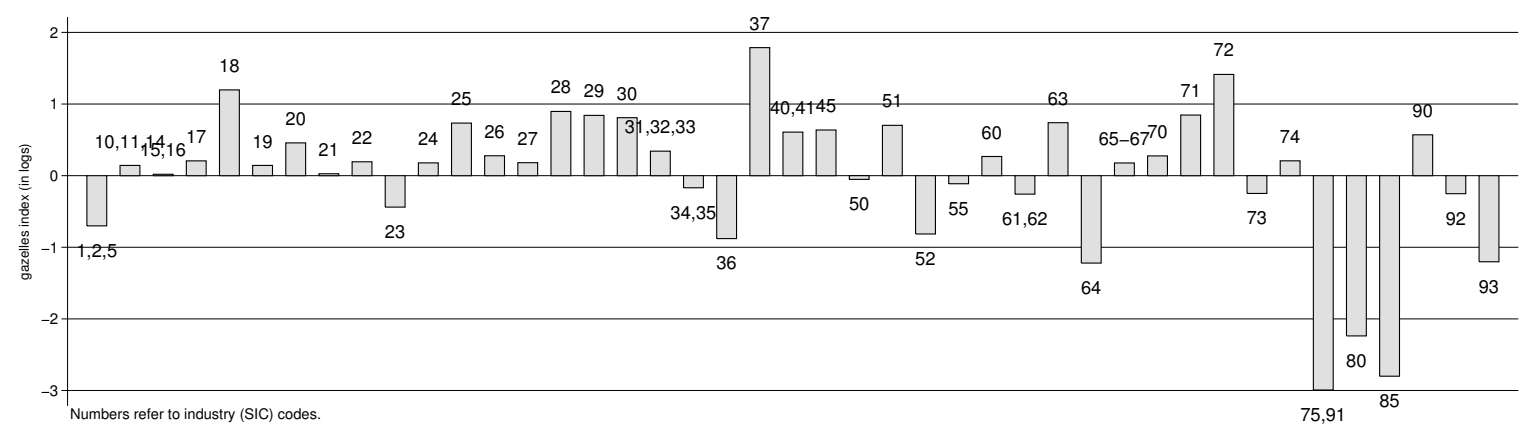

(d) Level effect of gazelles on industry growth

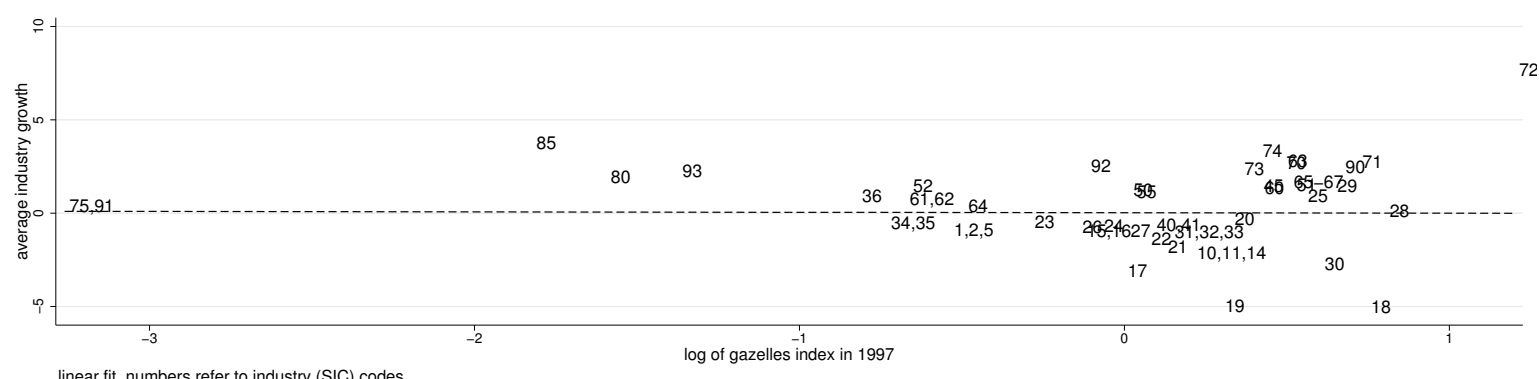


Table 1: Descriptive statistics

Panel A: Descriptives per industry

\begin{tabular}{|c|c|c|c|c|c|c|}
\hline industry & empl & yment & num & & & azelles \\
\hline Agriculture, forestry and fishery $(1,2,5)$ & 225.208 & $(13.694)$ & 1761 & $(269)$ & 73 & (12.419) \\
\hline Mining and quarrying $(10,11,14)$ & 8.583 & $(1.035)$ & 75 & (14) & 6 & $(1.267)$ \\
\hline Food, beverages and tabacco $(15,16)$ & 128.267 & $(8.934)$ & 1394 & (57) & 62 & $(6.552)$ \\
\hline Textiles (17) & 16.464 & $(2.715)$ & 260 & (29) & 9 & (3.601) \\
\hline Wearing apparel (18) & 5.492 & $(1.59)$ & 100 & (35) & 7 & $(3.06)$ \\
\hline Leather and leather products (19) & 2.638 & $(0.727)$ & 59 & (20) & 2 & $(0.707)$ \\
\hline Wood, cork and straw (20) & 18.833 & (1.607) & 378 & (22) & 14 & (3.704) \\
\hline Paper and paper products $(21)$ & 23.65 & (2.132) & 226 & (14) & 15 & $(4.008)$ \\
\hline Printing and reproduction of recorded media (22) & 85.8 & $(8.028)$ & 1096 & (79) & 51 & $(6.11)$ \\
\hline Coke and refined petroleum products (23) & 6.3 & $(0.358)$ & 22 & (6) & 3 & (1.049) \\
\hline Chemicals and chemical products (24) & 67.175 & (3.243) & 378 & (29) & 34 & $(4.166)$ \\
\hline Rubber and plastic products (25) & 32.892 & $(1.0$ & 485 & (17) & 31 & $(4.428)$ \\
\hline heral products (26) & 31.117 & & 400 & (34) & 15 & (2.918) \\
\hline Basi & 22.975 & $(1.9$ & 104 & (9) & 13 & $(2.896)$ \\
\hline & 96.592 & & 1893 & (111) & 119 & (20.133) \\
\hline & 86.5 & (2.653) & 1360 & $(82)$ & 90 & (15.744) \\
\hline mputers (30) & 6.827 & $(1.51)$ & 36 & (9) & 7 & (1.12) \\
\hline & 81.058 & & 652 & (70) & 51 & $(4.789)$ \\
\hline nent n.e.c. $(34,35)$ & 51.564 & $(3.5$ & 499 & (35) & 13 & (7.258) \\
\hline & 135.708 & & 728 & (67) & 33 & (6.095) \\
\hline & 2.6 & & 64 & (9) & 4 & (1.401) \\
\hline water $(40,41)$ & 31.245 & (2.126) & 75 & (12) & 18 & $(9.9)$ \\
\hline & 460.583 & (13. & 7487 & (596) & 382 & $(49.951)$ \\
\hline rade and services (50) & 133.1 & $(2.47$ & 2316 & (121) & 75 & (12.993) \\
\hline & 435.733 & $(12$. & 7062 & (671) & 400 & (43.643) \\
\hline & 479.017 & $(15.2$ & 4721 & (310) & 138 & (24.518) \\
\hline service activities (55) & 196.192 & & 2776 & (495) & 113 & $(27.88)$ \\
\hline & 179.617 & & 2742 & (85) & 153 & (28.034) \\
\hline & 49.282 & $(1.2$ & 199 & (27) & 13 & $(5.045)$ \\
\hline & 83.967 & & 1019 & (77) & 76 & (11.934) \\
\hline ication (64) & 96.158 & (10.269) & 219 & (55) & 33 & (12.501) \\
\hline-67$)$ & 251.1 & $(8.0$ & 1175 & (138) & 236 & (65.976) \\
\hline & 65.958 & & 950 & (127) & 60 & (12.986) \\
\hline pment (71) & 22.342 & $(1.838)$ & 331 & (34) & 25 & $(4.88)$ \\
\hline rvice activities (72) & 118.7 & $(18.1$ & 1180 & (376) & 218 & (45.771) \\
\hline$t(73)$ & 29.708 & $(0.96$ & 233 & (30) & 24 & (12.166) \\
\hline Other & 843.417 & (66.09) & 7347 & (1577) & 724 & (233.049) \\
\hline and (cociol) corric (75 01) & 455.227 & & 802 & (80) & 10 & $(3.573)$ \\
\hline Educa & 318.4 & $(17.4$ & 2702 & (357) & 37 & (12.011) \\
\hline & 753.517 & & 4147 & (258) & 73 & (39.975) \\
\hline & 25.517 & $(1.5 ?$ & 310 & (29) & 28 & $(6.151)$ \\
\hline Culture, sports and re & 112.767 & $(5.14)$ & 1834 & (200) & 57 & (16.375) \\
\hline Other services (93) & 162.683 & (6.558) & 619 & $(66)$ & 23 & (5.263) \\
\hline
\end{tabular}

Panel B: Variables used in panel VAR

\begin{tabular}{lrrrr}
\hline & Mean & \multicolumn{1}{l}{ Std. Dev. } & Min. & \multicolumn{1}{l}{ Max. } \\
\hline$\Delta$ gazelles & 3.770 & 32.810. & -100 & 307.143 \\
$\Delta$ industry & 0.149 & 4.318 & -25.581 & 29.412 \\
\hline
\end{tabular}


A change in the presence of gazelles within an industry is measured as the change in the percentage of firms in an industry that are gazelles. For the latter variable, we do not include cases where this change (positive or negative) is more than $100 \%$, resulting in the removal of 60 observations, and an almost balanced panel data set with a total of 500 observations, spanning 12 years (1997-2008). There is an important reason why we construct industry growth ( $\Delta$ industry) and the growth of the presence of gazelles $(\Delta$ gazelles) in this manner: by using the number of firms to generate the latter variable, and the total employment to construct the former, we try to ensure that both variables are not (or rather, the least) related by construction.

We make use of industry data at the two digit level supplied by the Netherlands Bureau of Statistics. An overview of the industries, their classifications and the key variables is given in Table 1 . Figure 1 shows the development of the number of gazelles and the sectoral employment.

Figure 1a shows three dominant trends in the structural change of the Netherlands economy (and in most advanced capitalist economies; see for example Lundquist et al., 2008: continuing decline of employment in the primary (agriculture) and secondary (manufacturing) sectors, a - fluctuating - increase of employment in business services (SIC 65-67, 70-74), and a continuing increase of employment in the semipublic sectors health care and education (SIC 80, 85). If we disaggregate to the (two-digit) industry level, we see two outliers on the upper side: SIC 72 (computer services; 223\% in 2008) and SIC 37 (recycling; $159 \%$ in 2009); and two outliners on the downside: SIC 19 (manufacture of leather (products); $47 \%$ in 2008) and SIC 18 (manufacture of wearing apparel; 50\% in 2008).

At the same time, Figure $1 \mathrm{~b}$ shows the evolution of the number of gazelles per industry over the period 1997-2008. Although the number of gazelles has decreased in modern manufacturing, in most industries we observe a (slight) increase until 2007, followed by a dip as the financial crisis set in.

Do we find that industries in which gazelles were, in relative terms, 'over represented' at the start of our sample period grow faster? Put differently, is it indeed the growth in the presence of gazelles that matters for industry growth, or is there a sizable level effect?

Figure 1c shows the gazelles index, based on 1997 data. The gazelles index is the ratio of the percentage of gazelles in the total population that are present in an industry, over the percentage of employment of that industry as part of the total population. Hence, a value of less than 0 for the index means an industry has relatively few gazelles, whereas values higher than 0 mean that gazelles are relatively frequent in an industry. Relatively few gazelles can be found in the public (SIC 75, 91) and semi-public industries (SIC 80, 85,92 ), while relatively many gazelles can be found in the energy industries (SIC 23), computer hardware (SIC 30), and computer software (SIC 72).

Figure $1 \mathrm{~d}$ sheds some light on the issue. In this figure, we compare average industry growth over the sample period with the gazelles index in 1997, the starting year of our sample. Figure 1d gives no evidence of a level effect. The correlation between the gazelle index and subsequent industry growth is close to zero. This seems to be in line with the study by Falck (2009) that also did not find industry-life cycle specific effects of the rate of (sustainable) start-ups on industry growth.

\subsection{Panel VAR}

In order to formalize the relationship between the developments in the number of gazelles and sectoral employment, we make use of a panel vector autoregression (PVAR) analysis (Love and Zicchino, 2006). With this type of analysis, we can explore the impulse responses of industry growth to a change in the presence of gazelles, and vice versa, while taking into account industry-specific effects. Figures $2 \mathrm{a}$ and $2 \mathrm{~b}$ serve to demonstrate the merits of this analysis. Each figure shows, in a stylized manner, the inter-temporal correlation between our two variables of interest. Each of the lines in Figure 2a represents a linear fit of the growth of employment on the growth of (the presence of) gazelles, but for different lagged values of the latter. For most lags the correlation appears to be positive, most strongly for the 3 year and 4 year lags. In one case (6 year lag), it is negative, due to a negative growth in employment in two sectors (office machinery and computing in 2008 and preparation for recycling in 2005). Without these two observations, we observe a (weak) positive correlation. 
Figure 2: The inter-temporal correlation between gazelles and sectoral employment

(a) (Inter)contemporaneous correlation of change in the number of gazelles and lagged employment growth

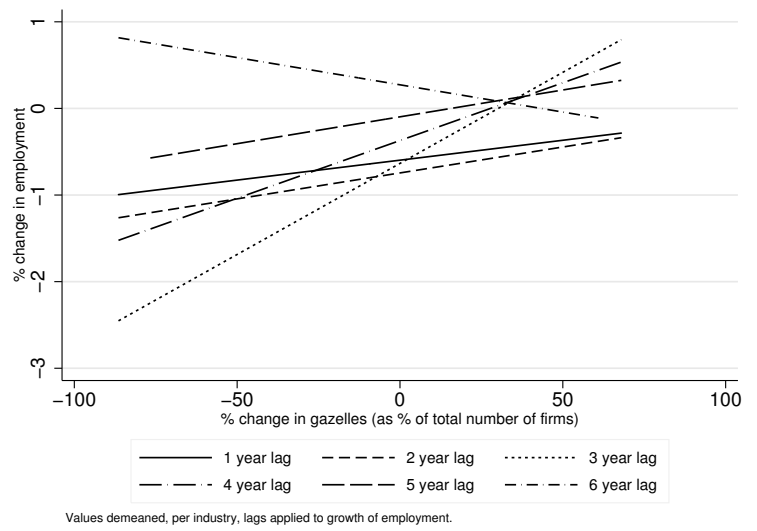

(b) (Inter)contemporaneous correlation of employment growth and lagged change in the number of gazelles

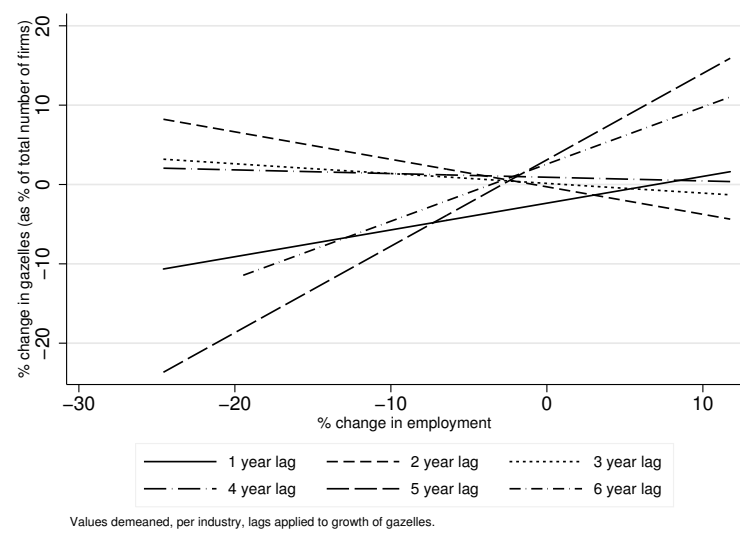

The same logic applies to Figure $2 b$, where we plot a linear fit of the growth of (the presence of) gazelles on the growth of employment, but for different lagged values of the latter. ${ }^{2}$ In sum, the relationship between industry growth and a change in the presence of gazelles appears to depend extensively on whether we consider it contemporaneously or otherwise. In addition, the relationship may go both ways, as high growth industries may provide a breeding ground for gazelles.

We therefore wish to explore the relationship between industry growth and the changes in the presence of gazelles in a more formal manner. Our aim is to find out what the short and long run effects are of a change in one variable (e.g., industry growth) on the other variable (e.g., the change in the presence of gazelles). To this end, we use a panel-data vector autoregression model, following Love and Zicchino (2006). The advantage of this PVAR model is that it allows for unobserved individual heterogeneity. ${ }^{3}$ We estimate:

$$
z_{i, t}=\Gamma_{0}+\Gamma_{1} z_{i, t-q}+f_{i}+e_{t}
$$

where $z_{t}$ is a two-variable vector that consists of industry growth and the growth in the presence of Gazelles. We set the number of lags included, $q$, at $3 .{ }^{4}$ In estimating the PVAR, we require that the underlying structure (i.e., the relation between the growth of gazelles and employment growth) is the same for each cross-sectional unit (i.e., each industry). However, we would like to allow for industry-specific effects, $f_{i}$. Since we use lags of the dependent variables in our analysis, these industry-specific effects would be correlated with these lags. We solve this problem by applying forward mean-differencing after time-demeaning our variables, instead of normal mean-differencing, thus removing the contemporaneous correlation (following Love and Zicchino, 2006). This Helmert transformation ensures the transformed variables and lagged regressors are still orthogonal, so we can use the latter as instruments and use GMM to estimate the PVAR. Finally, we use Monte Carlo simulations to obtain bootstrapped confidence intervals for the impulse response functions.

Table 2 contains the coefficient estimates. These results confirm our earlier observation, based on Figure $2 \mathrm{a}$, that the inter-temporal relationship between the growth of gazelles and industry growth is not constant.

\footnotetext{
${ }^{2}$ In this figure, correlation is (slightly) negative with 3- and 6-year lags, due to high negative growth in office machinery and computing (in 2002, for the 3-year lags and in 2008, for the 6-year lags).

${ }^{3}$ An alternative would be to use a structured VAR (SVAR). However, that approach would require a set of parameter restrictions, which are not obvious a priori in our case.

${ }^{4}$ Our results are robust to changing the lag length to 2 or 4 .
} 
Table 2: Panel VAR results

Panel A: Coefficients

\begin{tabular}{rrrrrrrr}
\hline \multicolumn{3}{c}{$\Delta$ gazelles } & & \multicolumn{3}{c}{$\Delta$ industry } \\
coeff. & se & $\mathrm{t}$ & $\Delta$ gazelles $_{t-1}$ & coeff. & se & $\mathrm{t}$ \\
\hline 0.124 & 0.081 & 1.534 & $\Delta$ gazelles $_{t-2}$ & 0.016 & 0.010 & 1.604 \\
0.296 & 0.087 & 3.405 & $\Delta$ gazelles $_{t-3}$ & -0.014 & 0.007 & -2.139 \\
0.155 & 0.079 & 1.946 & $\Delta$ industry $_{t-1}$ & 0.001 & 0.008 & 0.171 \\
0.908 & 0.565 & 1.605 & $\Delta$ industry $_{t-2}$ & 0.519 & 0.074 & 6.994 \\
0.063 & 0.615 & 0.103 & $\Delta$ industry $_{t-3}$ & -0.007 & 0.081 & -0.081 \\
0.521 & 0.464 & 1.123 & & -0.077 & 0.066 & -1.165 \\
\hline
\end{tabular}

Panel B: Variance decomposition

\begin{tabular}{lcc}
\hline & $\Delta$ gazelles & $\Delta$ industry \\
$\Delta$ gazelles & 0.959 & 0.041 \\
$\Delta$ industry & 0.015 & 0.985 \\
\hline
\end{tabular}

This is certainly the case for the second set of coefficients, with industry growth as a dependent variable, where we observe changing signs both for lagged growth of gazelles and lagged industry growth.

In Figures $3 \mathrm{a}$ and $3 \mathrm{~b}$, we plot the resulting cumulative impulse responses with $95 \%$ confidence intervals. The first thing to notice, is the relatively large confidence intervals in both cases: even after transforming the data, there is still considerable heterogeneity in the response of either industry growth or the growth of the presence of gazelles to a shock. In fact, although the impulse response of the latter to a shock to industry growth is in itself interesting, it is also never significantly different from zero. After an initial positive reaction in the growth of the presence of gazelles, the effect quickly wears off, and from Figure 3a we observe that there does not appear to be long run positive effect of an increase in industry growth on the growth in the presence of gazelles.

Figure 3: Cumulative impulse responses

(a) Effect on $\Delta$ gazelles of shock to $\Delta$ industry

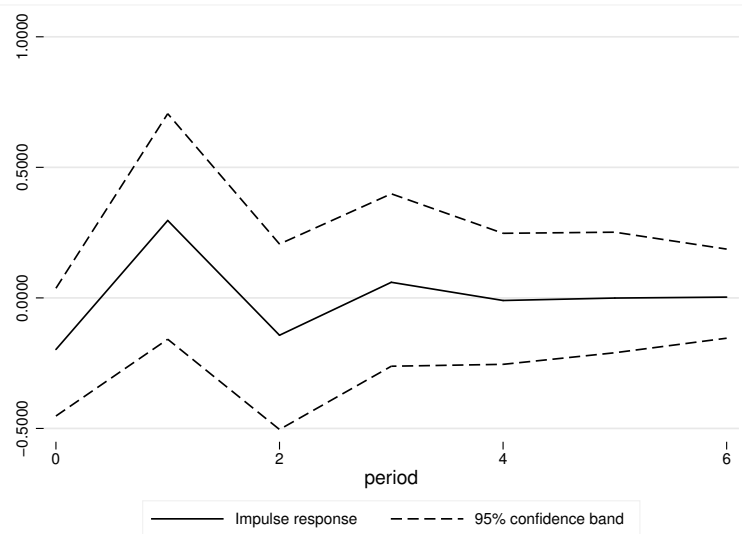

(b) Effect on $\Delta$ industry of shock to $\Delta$ gazelles

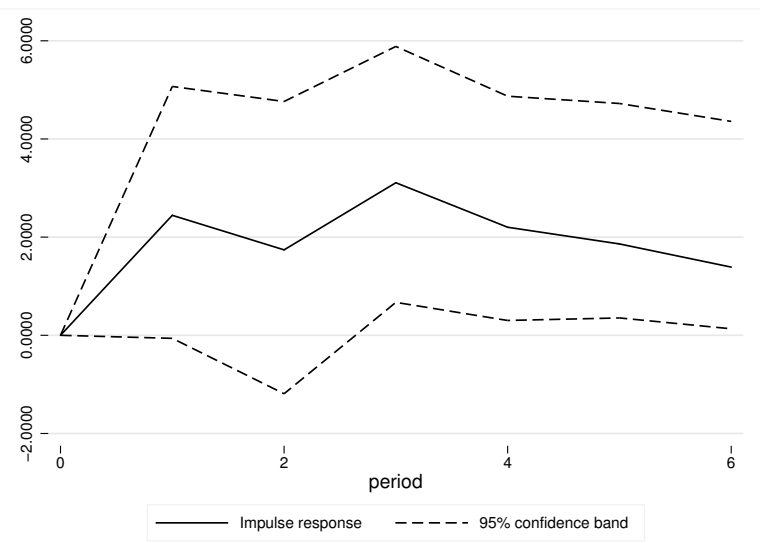

In Figure 3a, confidence intervals are also rather wide. However, here the cumulative impulse response is eventually significantly different from zero, even for the very heterogeneous sample under investigation 
here. What is more, the response of industry growth to an increase in the growth of the presence of gazelles increases for a number of periods, before slightly wearing off again. And a closer look reveals that the effect of a shock to the growth of the presence of gazelles carries significant weight, as evidenced by the relatively large cumulative response. Indeed, the variance decomposition in Panel B of Table 2 confirms that a much larger percentage of the variance in industry growth $(4.1 \%)$ is explained by variance in the growth of the presence of gazelles than vice versa $(1.5 \%)$.

In sum, these results show that the effect of gazelles on industry growth is both larger and more significant than the effect of industry growth on gazelles. Importantly, and as explained in our data section, there is a very low probability that we arrive at these findings by virtue of the variable construction. However, although the PVAR results suggest that gazelles affect industry growth much more than vice versa, we cannot be sure that we the former (latter) is a (lack of) causality. This is an issue that we shall investigate next.

\subsection{Causality}

Testing for (economic) causality is notoriously difficult. After all, what if a common factor drives both the growth in the presence of gazelles and industry growth? Testing for Granger causality is our next best option. However, to the best of our knowledge, there currently does not exist a Granger causality test for PVARs.

In order to still investigate whether there is evidence of one or two way causality, we resort to the following. First, we treat our panel data set as a pooled time series, in the same fashion as one would with a pooled cross-section. The distributions of our key variables are given in Figure 4a. Both growth rates depicted there are demeaned in the analyses, in order to make them more comparable, and as required for our panel VAR analysis. As Figure 4a shows, both growth rates are also approximately normally distributed, with a high kurtosis for the change in employment (our measure for industry growth) and a much larger standard deviation for the change in the presence of gazelles. Now, in principle we can resort to the standard Granger causality test for VARs.

Figure 4: Causality

(a) Distributions of growth

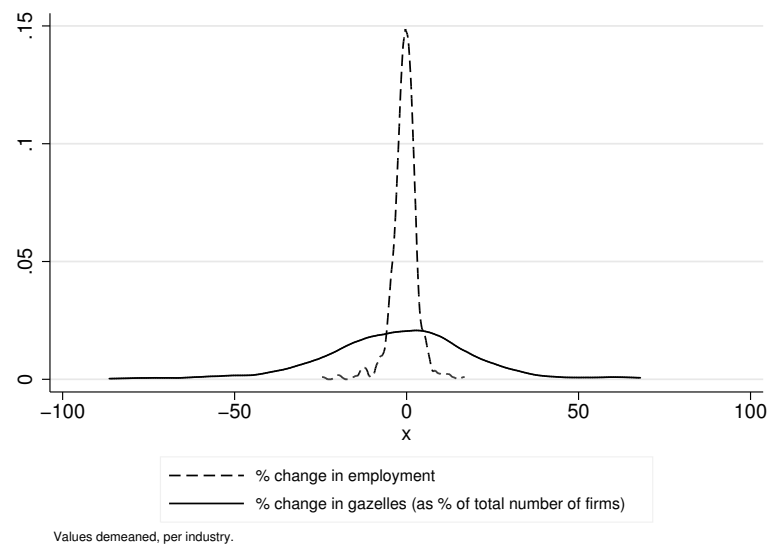

(b) Granger causality

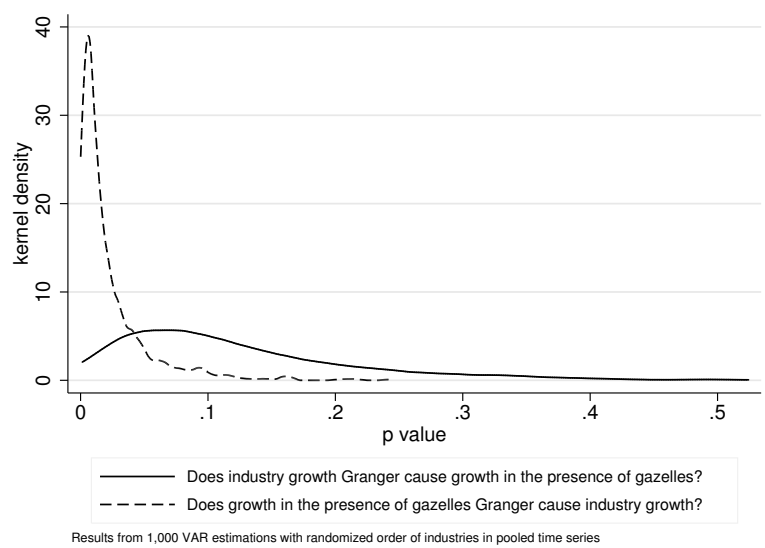

However, by treating our panel data set as a pooled time series, the order in which we have placed the industries may seriously bias our test results. To address this issue, we randomly sort industries in our data set, keeping the time dimension within each industry intact. We then test, and repeat this procedure 1,000 times. Figure $4 \mathrm{~b}$ shows the resulting distributions for the $\mathrm{p}$-values for tests whether the growth in the presence of gazelles Granger causes industry growth and vice versa. 
Clearly, it is hard to reject the null hypothesis that the growth in the presence of gazelles Granger causes industry growth. However, concerning the null hypothesis that industry growth Granger causes the growth in the presence of gazelles, we have to conclude that most of the density mass is distributed at p-values higher than $5 \%$. Summing up, these exploratory causality tests lend support to our interpretation of the PVAR results.

Summing up, the variance decompositions, impulse responses, and Granger-causality test suggest that it is the growth in the presence of gazelles that has contributed to industry growth, not the rate or level of particular start-ups.

\section{Discussion and conclusions}

Using a unique data set comprised of 43 industries over 12 years (1997-2008) covering the whole business population of the Netherlands, we examined to what extent gazelles influence the growth of industries. We find that an increase in the presence of gazelles in an industry has a positive effect on the subsequent growth of the industry. We do not find evidence for an inverse causal relation: there are no long run positive effects of increases in industry growth on the presence of gazelles. There is also no relation between the overrepresentation of gazelles and subsequent industry growth. This suggests that for the overall population of gazelles and industries in the Netherlands, the Schumpeterian explanation seems to be least applicable, that there is no evidence for the industry growth by spin-offs explanation (certainly not for the set of industries for which this mechanism would be most relevant: modern manufacturing). The Austrian explanation seems to make most sense, especially for the sectors which do not contain new industries, but new niches enabled by new technologies (e.g. computer services and product software; R\&D services) or new regulations (e.g. within the education and care sectors).

\subsection{Limitations}

Even though virtually no prior empirical tests have examined whether and to what extent the (growth in the) presence of gazelles enhances the growth of industries over long periods, spanning a diverse set of industries, this study is not without limitations.

Our industry classification can be regarded as too broad: it is much less fine grained than those used in other industry life cycle studies that are based on specific product-markets (see for example Gort and Klepper, 1982; Agarwal, 1998; Dinlersoz and MacDonald, 2009. However, a more narrow industry classification would probably lead to problems in the empirical analyses, because too few cases per industry would remain to do quantitative analyses. Our industry classification also misses new emerging industries, because census bureau industry classifications always lag behind new industrial developments in the real world. However, most of these new industries are probably captured in related industries, like for example internet firms in the telecommunications SIC (64).

Our results may not generalize outside the specific period of the study (1997-2008: including the Internet boom, bust and start of recession) and the specific national context (The Netherlands). In addition, testing for underlying (unobserved) variables that affect both the growth of the number of gazelles and industry growth - for example the development of the financial sector (Rajan and Zingales, 1998), macroeconomic growth, and agglomeration economies (Van Oort and Stam, 2009) - might also improve the robustness of the results found in this studies. Other robustness tests might include analyses with other definitions of gazelles, for example with other growth measures and/or age groups (cf. Davidsson and Delmar, 2006; Acs, 2008; OECD, 2008; Falkenhall and Junkka, 2009), and analyses that include independent start-ups and newly created corporate entities.

\subsection{Implications for public policy}

Gazelles are perceived as signposts of future economic development: however, we have not found any evidence that the overrepresentation of gazelles in a particular industry is a predictor of subsequent industry growth. Contrasting evidence can for example be found in the IT industries: while both computer hardware and computer software industries have relatively many gazelles, the computer hardware 
industry declined in employment size, while the computer software industry has grown considerably. ${ }^{5}$ The semi-public industries care and education have relatively few gazelles, but have been growing enormously in employment. Our finding that the overrepresentation of gazelles in a particular industry is not a predictor of subsequent industry growth has implications for industrial policy. It means that the overrepresentation of gazelles in a particular industry cannot be used as a signpost for 'picking winners', i.e. industries that are likely to grow in the near future. ${ }^{6}$

We did find that growth in the presence of gazelles in a particular industry is a predictor of subsequent (1-6 years) industry growth. So gazelles seem to be early movers with respect to the recognition and realization of industry specific (growth) opportunities. Two distinctive sets of industries seem to be driven by the growth in the number of gazelles. On the one hand the new technology industries, computer services, telecommunications, and R\&D services. On the other hand, gazelles seem to be important vehicles for new job creation/realization in semi-public industries that are liberalized (nursing and midwifery, care at home for the elderly and disabled) or receive extra public funding (child daycare). This means that gazelles are instrumental for structural change in two ways: for the growth of internationally competitive knowledge based (service) sectors and for the growth of semi-public sectors that serve the welfare state.

Taking away the barriers for the growth of new firms (in industries of their own choice; i.e. horizontal industrial policy) is a no-regret policy that is likely to enhance job creation in general (see Henrekson and Johansson, 2009 and Stam and Nooteboom, 2011 for a review of institutional conditions for high growth firms and innovative firms). In addition, if industrial targeting is deemed to be necessary for strategic trade reasons, then industries in which the share of gazelles is rapidly increasing might be favorable candidates for industrial targeting. And, finally, gazelles might be instrumental in the realization of public interests, for example in healthcare, education and environmental industries.

\section{References}

Acs, Z. and Mueller, P. (2008). Employment effects of business dynamics: Mice, gazelles and elephants. Small Business Economics, 30(1):85-100

Acs, Z. J. (2008). Foundations of high impact entrepreneurship. Foundations and Trends in Entrepreneurship, 4(6):535-620.

Acs, Z. J., Parsons, W., and Spencer, T. (2008). High impact firms: Gazelles revisited. Technical report, Office of Advocacy Working Paper, U.S. Small Business Administration.

Agarwal, R. (1998). Evolutionary trends of industry variables. International Journal of Industrial Organization, 16(4):511-525.

Arrow, K. (1962). Economic welfare and the allocation of resources for inventions. In Nelson, R., editor, The Rate and Direction of Inventive Activity, Princeton, N.J. Princeton University Press.

Audretsch, D., Keilbach, M., and Lehmann, E. (2006). Entrepreneurship and Economic Growth. Oxford University Press, Oxford.

Baumol, W. J., Panzar, J. C., and Willig, R. D. (1988). Contestable markets and the theory of industry structure. Harcourt Brace Jovanovich, San Diego, revised edition edition.

Bosma, N. (2009). The Geography of Entrepreneurial Activity and Regional Economic Development. Multilevel analyses for Dutch and European Regions. PhD thesis, Utrecht University.

Carree, M., Van Stel, A., Thurik, R., and Wennekers, S. (2007). The relationship between economic development and business ownership revisited. Entrepreneurship \& Regional Development: An International Journal, 19(3):281-291.

Christensen, C. M. (1997). The innovator's dilemma: When new technologies cause great firms to fail. Harvard Business School Press, Boston.

Davidsson, P. and Delmar, F. (2006). High-growth firms and their contribution to employment: The case of Sweden. In Davidsson, P., Delmar, F., and Wiklund, J., editors, Entrepreneurship and the growth of firms, pages 156-178, Cheltenham, UK. Edward Elgar.

Dinlersoz, E. M. and MacDonald, G. (2009). The industry life-cycle of the size distribution of firms. Review of Economic Dynamics, 12(4):648-667.

Eckhardt, J. T. and Shane, S. A. (2011). Industry changes in technology and complementary assets and the creation of high-growth firms. Journal of Business Venturing, In press, corrected proof:-.

Eliasson, G. (1991). Deregulation, innovative entry and structural diversity as a source of stable and rapid economic growth. Journal of Evolutionary Economics, 1(1):49-63.

Falck, O. (2007). Mayflies and long-distance runners: the effects of new business formation on industry growth. Applied Economics Letters, 14(12):919-922.

Falck, O. (2009). New business formation, growth, and the industry lifecycle. In Cantner, U., Gaffard, J.-L., and Nesta, L., editors, Schumpeterian Perspectives on Innovation, Competition and Growth, pages 299-312, Dordrecht. Springer.

\footnotetext{
${ }^{5}$ With the commercial failure of the national computer hardware manufacturers Philips and Tulip in the 1990s, and the downsizing of large foreign multinationals (like Xerox and NEC) and Océ in the 2000s.

${ }^{6}$ Of course, one possible explanation is that gazelles are relatively capital-intensive, and as a result employ fewer people to produce the same amount of value added.
} 
Falkenhall, B. and Junkka, F. (2009). High-growth Firms in Sweden 1997-2007. Characteristics and development patterns. The Swedish Agency for Growth Policy Analysis, Stockholm.

Fritsch, M. (2008). How does new business formation affect regional development? introduction to the special issue. Small Business Economics, 30(1):1-14.

Fritsch, M. and Schroeter, A. (2009). Are more start-ups really better? quantity and quality of new businesses and their effect on regional development. Jena Economic Research Papers 2009-070, Friedrich-Schiller-University Jena, Max-Planck-Institute of Economics.

Gort, M. and Klepper, S. (1982). Time paths in the diffusion of product innovations. The Economic Journal, 92(367):630-653.

Henrekson, M. and Johansson, D. (2009). Competencies and institutions fostering high-growth firms. Foundations and Trends in Entrepreneurship, 5(1):1-80.

Hvide, H. K. (2009). The quality of entrepreneurs. The Economic Journal, 119(539):1010-1035.

Kirzner, I. M. (1997). Entrepreneurial discovery and the competitive market process: An Austrian approach. Journal of Economic Literature, 35(1):60-85.

Klepper, S. (1996). Entry, exit, growth, and innovation over the product life cycle. The American Economic Review, 86(3):562-583.

Klepper, S. (2002). The capabilities of new firms and the evolution of the US automobile industry. Industrial and Corporate Change, 11(4):645-666.

Krugman, P. R. (1986). Strategic Trade Policy and the New International Economics. MIT Press, Cambridge, Massachussetts.

Krugman, P. R. (1993). The current case for industrial policy. In Salvatore, D., editor, Protectionism and world welfare, pages 160-179, Cambridge. Cambridge University Press.

Lerner, J. (2010a). Boulevard of Broken Dreams: Why Public Efforts to Boost Entrepreneurship and Venture Capital Have Failed-and What to Do About It. Princeton University Press, Princeton.

Lerner, J. (2010b). The future of public efforts to boost entrepreneurship and venture capital. Small Business Economics, 35(3):255-264.

Love, I. and Zicchino, L. (2006). Financial development and dynamic investment behavior: Evidence from panel var. The Quarterly Review of Economics and Finance, 46(2):190-210.

Lundquist, K.-J., Olander, L.-O., and Henning, M. S. (2008). Producer services: growth and roles in long-term economic development. The Service Industries Journal, 28(4):463-477.

Metcalfe, J. S., Foster, J., and Ramlogan, R. (2006). Adaptive economic growth. Cambridge Journal of Economics, 30(1):7-32.

Mowery, D. and Nelson, R. (1999). Sources of Industrial Leadership. Studies of seven industries. Cambridge University Press, Cambridge. OECD (2008). Measuring Entrepreneurship. A digest of indicators. OECD-Eurostat Entrepreneurship Indicators Program, Paris.

Rajan, R. G. and Zingales, L. (1998). Financial dependence and growth. The American Economic Review, 88(3):559-586.

Rosenberg, N. (1992). Economic experiments. Industrial and Corporate Change, 1(1):181-203.

Saxenian, A. (1994). Regional advantage: Culture and competition in Silicon Valley and Route 128. Harvard University Press, Cambridge, MA.

Schumpeter, J. . (1942). Capitalism, Socialism, and Democracy. Harper and Brothers, New York.

Schumpeter, J. (1934). The theory of economic development. Harvard University Press, Cambridge, MA.

Stam, E. (2005). The geography of gazelles in the netherlands. Journal for Economic and Social Geography (TESG), 96(1):121-127.

Stam, E. (2007). Why butterflies don't leave: Locational behavior of entrepreneurial firms. Economic Geography, 83(1):27-50.

Stam, E., Hartog, C., Van Stel, A., and Thurik, R. (2011). Ambitious entrepreneurship, high-growth firms and macroeconomic growth. In Minniti, M., editor, The Dynamics of Entrepreneurship: Theory and Evidence, Oxford. Oxford University Press.

Stam, E. and Martin, R. (2011). When high tech ceases to be high growth: The loss of dynamism of the Cambridgeshire region. TKI working paper, Utrecht University School of Economics.

Stam, E. and Nooteboom, B. (2011). Entrepreneurship, innovation and institutions. In Audretsch, D., Falck, O., and Heblich, S., editors, Handbook of Research on Innovation and Entrepreneurship, Cheltenham, UK. Edward Elgar.

Stam, E., Suddle, K., Hessels, J., and Van Stel, A. (2009). High-growth entrepreneurs, public policies and economic growth. In Leitao, J. and Baptista, R., editors, Public Policies for Fostering Entrepreneurship: A European Perspective., pages 91-110, New York. Springer.

The Economist (2010). The global revival of industrial policy. picking winners, saving losers. industrial policy is back in fashion. have governments learned from past failures? The Economist, August 5.

Van Oort, F. G. and Stam, E. (2009). Agglomeration economies and firm growth: testing for spatial externalities in the Dutch ICT industry. In Johansson, B., Karlsson, C., and Stough, R., editors, Innovation, Agglomeration, and Regional Competition, pages 346-374, Cheltenham. Edward Elgar.

Wennekers, S. and Thurik, R. (1999). Linking entrepreneurship and economic growth. Small Business Economics, 13(1):27-56.

Witt, U. (2003). Economic policy making in evolutionary perspective. Journal of Evolutionary Economics, 13(2):77-94. 


\section{Appendix: disaggregate analysis}

In applying our panel VAR model to our entire data set, there may still be some concerns over possible aggregation bias, masking industry heterogeneity. As a robustness check, we therefore repeat the analysis, this time at a lower aggregation level.

Figures A.1a-A.1d below show the impulse responses from panel VAR analyses carried out as before, but for each distinct group that contains sufficient cross-sectional variation. Overall, these analyses confirm our earlier findings: shocks to industry growth have little to no effect on the growth of gazelles, whereas shocks to the growth of gazelles do have an effect on industry growth. After 6 years, the average effect of the latter shock is positive, except in modern manufacturing (in which most industries faced a decline in the number of gazelles, but not always a decline in employment growth). However, the confidence interval is sufficiently wide to also cover a zero effect in most cases, confirming that there may still be a lot of heterogeneity left in the response to the growth of gazelles.

Figure A.1: Impulse responses for lower aggregation level analysis

(a) Traditional manufacturing $(15-22,26,36)$

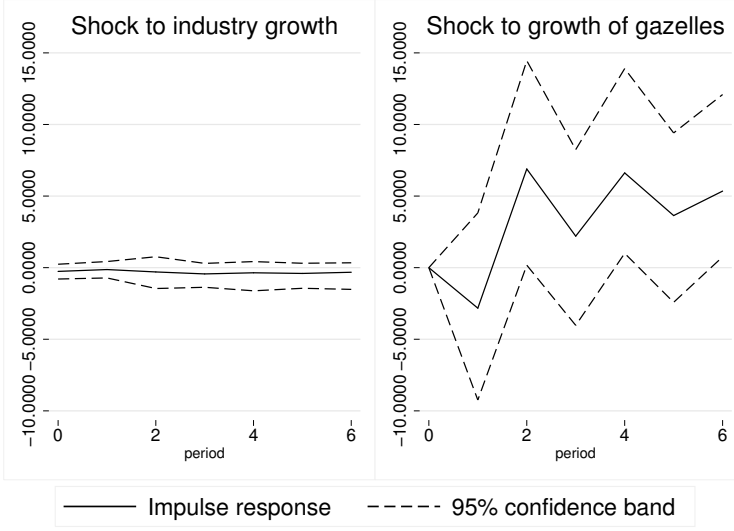

(c) Business services $(45,51,60-67,70-74)$

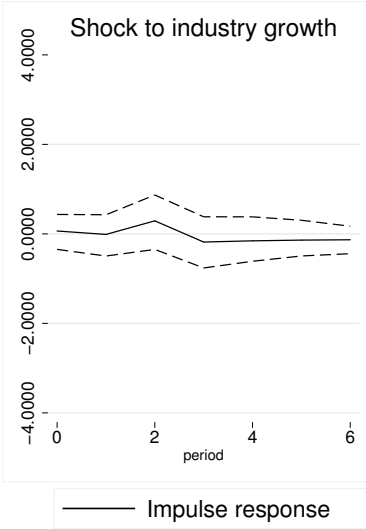

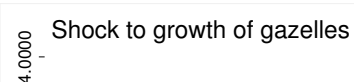

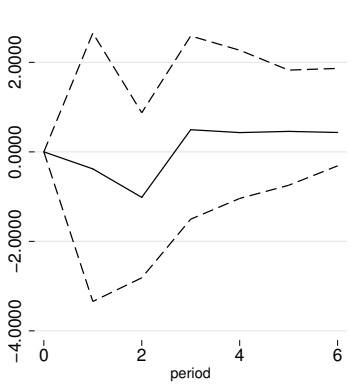

- $95 \%$ confidence band (b) Modern manufacturing (23-25, 27-35, 37)

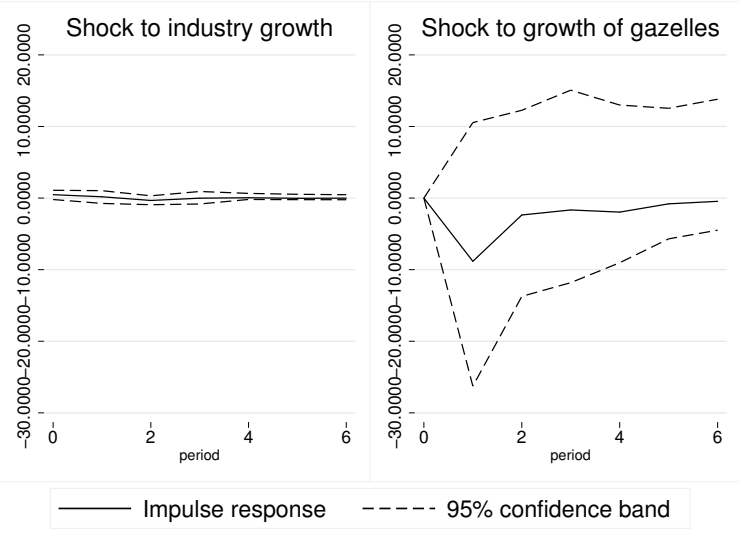

(d) Semi-public services (40, 41, 50, 80, 85, 90-93)

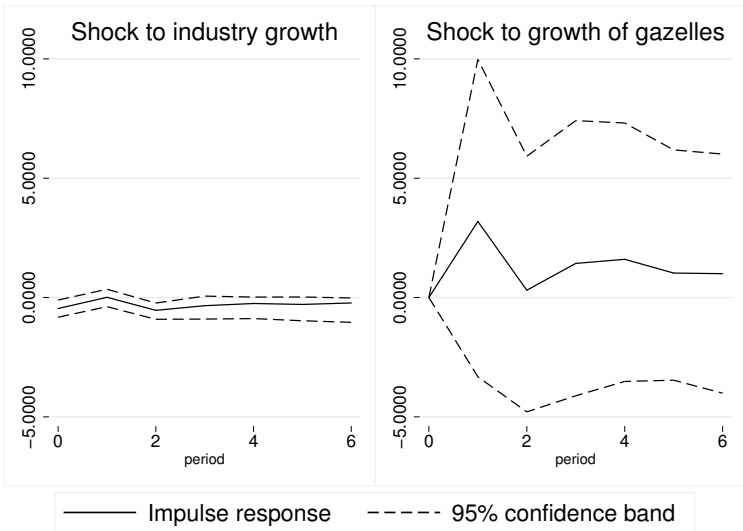

For two of our groups, the primary sector and personal services, our data do not yield enough crosssectional variation for a panel VAR and a bootstrap analysis. For these two groups, we take annual (employment weighted) averages and repeat the analysis using a simple VAR model. Our results are qualitatively similar to what has been shown for the other groups above. ${ }^{7}$

\footnotetext{
${ }^{7}$ Results are available upon request.
} 